International Journal of Physical Research, $8(2)(2020) 60-66$
SPC
Website: $w w w . s c i e n c e p u b c o . c o m / i n d e x . p h p / I J P R$
Research paper

\title{
Radiological risk assessment of some consumed cigarettes and hookah in Iraq
}

\author{
Sahar Ahmed Amin ${ }^{1}$ *, Azhar Mahmood Haleem ${ }^{2}$, Ola Hamed Mahmood ${ }^{3}$ \\ ${ }^{1}$ Environmental Research Center, University of Technology, Baghdad, Iraq \\ *Corresponding author E-mail: sahar.a.amin@uotechnology.edu.iq
}

\begin{abstract}
The main purposes of the research are to assess the radiological risk due to smoking cigarettes and hookah and their impacts on the people health. Radon levels were measured in 28 consumed brands of cigarettes and 10 brands of hookah consumed Iraq using CR-39 solid state nuclear track detectors (SSNTDs). The results showed that the $222 \mathrm{Rn}$ concentration in cigarette tobacco samples ranged from 138.9 to 781.2 Bqm-3 with average value of $318.0 \mathrm{Bqm}-3$. The radon concentrations emerged from $11 \mathrm{brands}$ of the investigated samples was significantly higher than the recommended value. While, its concentration in hookah ranged from 633.6 Bqm-3 to 416.6 Bqm-3 with average value of 509.5 Bqm-3. The Potential Alpha Energy Concentration (PAEC) in terms of (WL) units, Exposure to radon progeny (EP), and the annual effective dose (AED) in terms of $(\mathrm{mSv} / \mathrm{y})$ units were also obtained. Lung cancer cases per year per million people (CPPP) are also evaluated with an average value of 144.4 per million people. The result indicates that the average values of PAEC, EP and AED were within the recommended range values given by UNSCEAR, NCRP and ICRP respectively. The radioactive impact of smoking is considered as a risk factor for lung cancer.
\end{abstract}

Keywords: Cigarettes; CR-39; Hookah; Radioactivity; Radon.

\section{Introduction}

Tobacco is a cultivation production prepared from green leaves of plants in the genus Nicotania. Tobacco also consists of small amount of radioisotopes that cause a radiation exposure hazard to smokers and passive smokers. Most humans became aware that the smoke of cigarette and tobacco has many toxic substances for example tar, arsenic, nicotine and cyanide. The common risks of cigarettes have been recognized for years. Yet, few humans realize that tobacco also contains radioactive materials: polonium-210 and lead-210. The combination of the toxic and radioactive materials in cigarettes hurt smokers. They also hurt persons subjected to secondhand smoke.

The radioactive isotope, Polonium-210, in cigarettes rests in "hot spots" in the lungs is one of the reasons which cause cancer [1]. Polonium is an alpha emitter which has a very damaging impact on lungs tissues. Alpha particles are a double positive charge which has very high ionizing energy that expended in the lung tissues and travels a limited range in the materials which it interacts with [2]. During its movement through the lung tissues it can produce a great numbers of ion pairs which in turn may cause cancer and may lead to thousands of deaths a year.

Since alpha particles can be stopped by the dead layer of the skin, then they are much less harmful than when they inter the blood stream, breathed in or ingested [3].

Smokers have the most serious danger of lung malignant growth. The danger of lung malignant growth increases with the length of smoking period and number of cigarettes consumed in a day. If they stopped smoking for a long time, they can lower the probability of malignant growth [4].

As indicated by the BEIR IV report of the US National Academies of Sciences and as per Pennsylvania Department of Environmental Protection, smokers were 10 and 6 times probable to get lung cancer than non-smokers, respectively. So, being a smoker is one of the factors that increase the possibility of developing radon induced lung cancer $[5,6]$.

Radioactive material from tobacco smoke is considered as the $2^{\text {nd }}$ major reason of global death as reported by World Health Organization (WHO). In whatever the way of consuming tobacco will result in different amounts of radioactive material to be entered the smoker's bloodstream. This causes the smoker to be exposed to a level of radioactive material that in a time can lead to different type of diseases like cancer, ulcer, leukemia and many other ailments [7]. Therefore, many countries impose strict conditions such as a minimum smoking age, adjust the purchasing and using of tobacco merchandise.

Hence, the perspective goals of this research are: (1) determination of radioisotopes level in most consumed brands of cigarettes in Iraq. (2) Calculation of risk indices such as (The Potential Alpha Energy Concentration (PAEC) in terms of (WL) units, radon progeny exposure (RP), and the annual effective dose $\left(\mathrm{ED}_{\mathrm{A}}\right)$ ). (3) To point up conclusions on hazardous impact of radioactivity due to smoking cigarettes and hookah. 


\section{Materials and methods}

Twenty-eight different brands of cigarettes and10 hookah flavor samples were collected from cigarettes shops. Tables 1 and 2 illustrate the coding of the studied cigarette and hookah flavor samples.

Table 1: Investigated Tobacco Brands and Their Production Country

\begin{tabular}{|c|c|c|c|}
\hline No & Brand & Code & Production Country \\
\hline 1 & Jewels Chocolate & JW & \\
\hline 2 & OSCAR (Ice cold) & OS1 & USA \\
\hline 3 & Senator (Red) & SR1 & Russia \\
\hline 4 & Marlboro & MB & USA \\
\hline 5 & Master & MS & USA \\
\hline 6 & ESSE (blue) & ES1 & Korea \\
\hline 7 & P\&S (balck) & PS1 & USA \\
\hline 8 & mond & MO & UAE \\
\hline 9 & Akhtamar & $\mathrm{AK}$ & Armenia \\
\hline 10 & Maxico (Red) & MX & \\
\hline 11 & Titan & TT & \\
\hline 12 & MT BLUE & MT & Armenia \\
\hline 13 & OSCAR (silver) & OS2 & USA \\
\hline 14 & West (fusion black) & WT2 & Germany \\
\hline 15 & MAC & MC & Denmark \\
\hline 16 & Senator (green) & SG2 & Russia \\
\hline 17 & Pine & $\mathrm{PN}$ & Korea \\
\hline 18 & West (silver) fusion white & WT1 & Germany \\
\hline 19 & P\&S (Silver) & PS2 & USA \\
\hline 20 & Gauloises (gold) & GL1 & France \\
\hline 21 & ESSE (silver) & ES3 & Korea \\
\hline 22 & Royale & RO & India \\
\hline 23 & GAULOISES compact (red) & GL2 & France \\
\hline 24 & ESSE (Black) & ES2 & Korea \\
\hline 25 & Sumer & SU & Iraq \\
\hline 26 & Bond & $\mathrm{BO}$ & USA \\
\hline 27 & Craven "A" & $\mathrm{CR}$ & UK \\
\hline 28 & Philip Morris (blue) & $\mathrm{PM}$ & USA \\
\hline
\end{tabular}

Table 2: Investigated Hookah Brands and Their Production Country

\begin{tabular}{|c|c|c|c|}
\hline No & Brand & Code & \\
\hline 1 & Mazaya, natural lemon molasses & MZ1 & Jorden \\
\hline 2 & Mazaya, natural lemon with mint molasses & MZ2 & Jordan \\
\hline 3 & Mazaya, natural kiwi with lemon molasses & MZ3 & Jordan \\
\hline 4 & Al Fakher, orange mint & FR & UAE \\
\hline 5 & Adalia, Lemon mint & $\mathrm{AD}$ & Turkey \\
\hline 6 & Al Fakhamah, lemon mint & FM & UAE \\
\hline 7 & Al Amasi, lemon mint & $\mathrm{AM}$ & Jordan \\
\hline 8 & Zain, castro & $\mathrm{ZC}$ & Jordan \\
\hline 9 & Razan, Lemon mint & RZ & Jordan \\
\hline 10 & Debaj, GUM & DJ & UAE \\
\hline
\end{tabular}

Five grams of each tobacco samples was put in plastic containers while the weight of each hookah flavor samples was 10 grams also put in plastic containers. The height of the container was $7.5 \mathrm{~cm}$ and $6.5 \mathrm{~cm}$ in diameter. A piece of CR-39 detector with area $(1 \mathrm{x} 1) \mathrm{cm}^{2}$ was sticked on the inside face of the container's cover (Figure 1). Each sample was replicated 3 times.

The containers were left at room temperature for two months exposure time. During this time alpha particles from the decay of radon, and its daughters fall on the CR-39 nuclear track detectors. Then, after the exposure time, alpha tracks on CR-39 detectors were developed using $6.25 \mathrm{~N} \mathrm{NaOH}$ etching solution at temperature $70^{\circ} \mathrm{C}$ for $5 \mathrm{~h}$. After chemical etching $\mathrm{Cr}-39$ pieces were washed with distilled water and prepared for counting the tracks with an optical microscope.

Alpha tracks recorded on CR-39 detector represent ${ }^{222} \mathrm{Rn}$ component, so the concentration of ${ }^{222} \mathrm{Rn}$ was assumed as directly proportional to the track density [8-10]

The calculated ${ }^{222} \mathrm{Rn}$ concentrations in the study brand tobacco and hookah samples $(\mathrm{C})$ in $\left(\mathrm{Bq} \cdot \mathrm{m}^{-3}\right)$ were according to the equation (1) [11]:

$\mathrm{C}=\frac{\text { Track density }\left(\mathrm{Tr}_{\mathrm{cm}} \mathrm{cm}^{-2}\right)}{\text { Calibration factor } \times \text { Exposure time }}=\frac{\rho}{\mathrm{kt}}$

Where $\mathrm{k}$ was found experimentally to be equal to (0.04891Track $\left.\mathrm{cm}^{-2} \mathrm{~d}^{-1} / \mathrm{Bq} \mathrm{m}^{-3}\right)$ [12].

The concentration of radon in the study cigarette brand samples $\left(\mathrm{C}_{\mathrm{Rn}}\right)$ was calculated by utilizing equation (2) suggested by Somogyi et al. [1986]. They proposed that the number of radon atoms emitted from the sample is equal to the number of radon atoms in the air above the sample times the decay probability, which can be written in the following form [13], [14]:

$\mathrm{C}_{\mathrm{Rn}}\left(\mathrm{Bq} / \mathrm{m}^{3}\right)=\frac{\mathrm{C} \lambda \mathrm{ht}}{\mathrm{L}}$ 
Where: $\lambda$ : decay constant for $\left({ }^{222} \mathrm{Rn}\right), \mathrm{h}$ : sample surface to detector distance $(\mathrm{cm})$, t: time of exposure $=60$ day, L: height of the sample (cm).

The Potential Alpha Energy Concentration (PAEC) in terms of (WL) units was calculated utilizing equation (3) [15-17]:

$\operatorname{PAEC}(\mathrm{WL})=\mathrm{F} \times \frac{\mathrm{C}}{3700}$

UNSCEAR (2000) proposed that $(\mathrm{F})$ is the equilibrium factor between radon and its progeny and it is $=0.4$.

Equation (4) shows the relation between the exposures to radon progeny (EP) with the average radon concentration $\mathrm{C}$ [18]:

$\mathrm{EP}\left(\mathrm{WLMY}^{-1}\right)=8760 \times \mathrm{n} \times \mathrm{F} \times \frac{\mathrm{C}}{170 \times 3700}$

Where $\mathrm{C}$ is in Bq. $\mathrm{m}^{-3}, \mathrm{n}=0.8$ (the fraction of time spent indoors), $8760=$ hours $/$ year, $170=$ number of hours $/$ working month.

Furthermore, the annual effective dose (AED) in units of (mSv/y) was also calculated using equation (5) [19-21]:

$\operatorname{AED}\left(\mathrm{mSv} \cdot \mathrm{y}^{-1}\right)=\mathrm{C} \times \mathrm{F} \times \mathrm{H} \times \mathrm{T} \times \mathrm{D}$

Where $\mathrm{H}=0.8$ (the occupancy factor), $\mathrm{T}=8760 \mathrm{~h} \cdot \mathrm{y}^{-1}$, and $\mathrm{D}=9 \times 10^{-6} \mathrm{mSv} /\left(\mathrm{Bq} \cdot \mathrm{h} \cdot \mathrm{m}^{-3}\right.$ ) (the dose conversion factor).

Then (CPPP), which is the number of lung cancer cases per year per million people, was calculated using the following equation [16], [22], [23]:

$\mathrm{CPPP}=\mathrm{AED} \times\left(18 \times 10^{-6} \mathrm{mSv}^{-1} \cdot \mathrm{y}\right)$

\section{Results and discussion}

\subsection{Tobacco samples}

Table 3 displays the calculated values of $\mathrm{C}, \mathrm{C}_{\mathrm{Rn}}, \mathrm{PAEC}, \mathrm{EP}, \mathrm{AED}$ and CPPP in the measured tobacco cigarette samples.

Table 3 Radon gas concentration $(C)$ in the can air above the samples, Radon gas concentration in the various brand tobacco samples $(\mathrm{CRn})$, potential alpha energy concentration (PAEC), exposure to radon progeny (EP), annual effective dose (AED), and lung cancer cases per year per million persons (CPPP)

Table 4: Radon Gas Concentration (C) in the Can Air above the Samples,

\begin{tabular}{|c|c|c|c|c|c|c|}
\hline Code & $\mathrm{C}$ Bq. $\mathrm{m}^{-3}$ & $\begin{array}{l}\mathrm{CRn} \text { Bq.m } \\
3\end{array}$ & PAEC (mWL) & EP (WLM.y $\left.{ }^{-1}\right)$ & $\operatorname{AED}\left(\mathrm{mSv} \cdot \mathrm{y}^{-1}\right)$ & $\mathrm{CPPP} \times 10^{-} 6$ \\
\hline JW & 208.3 & 18.5 & 22.5 & 0.928 & 5.255 & 94.6 \\
\hline SR1 & 243.0 & 21.6 & 26.3 & 1.083 & 6.131 & 110.4 \\
\hline $\mathrm{SG} 2$ & 538.1 & 47.7 & 58.2 & 2.398 & 13.577 & 244.4 \\
\hline MB & 277.7 & 24.6 & 30.0 & 1.238 & 7.007 & 126.1 \\
\hline MS & 486.1 & 43.1 & 52.5 & 2.166 & 12.263 & 220.7 \\
\hline ES1 & 347.2 & 30.8 & 37.5 & 1.547 & 8.759 & 157.7 \\
\hline ES2 & 277.7 & 24.6 & 30.0 & 1.238 & 7.007 & 126.1 \\
\hline ES3 & 243.0 & 21.6 & 26.3 & 1.083 & 6.131 & 110.4 \\
\hline PS1 & 138.9 & 12.3 & 15.0 & 0.619 & 3.504 & 63.1 \\
\hline PS2 & 208.3 & 18.5 & 22.5 & 0.928 & 5.255 & 94.6 \\
\hline MO & 347.2 & 30.8 & 37.5 & 1.547 & 8.759 & 157.7 \\
\hline AK & 191.0 & 16.9 & 20.6 & 0.851 & 4.817 & 86.7 \\
\hline MX & 225.7 & 20.0 & 24.4 & 1.006 & 5.693 & 102.5 \\
\hline TT & 173.6 & 15.4 & 18.8 & 0.774 & 4.379 & 78.8 \\
\hline MT & 295.1 & 26.2 & 31.9 & 1.315 & 7.445 & 134.0 \\
\hline OS1 & 486.1 & 43.1 & 52.5 & 2.166 & 12.263 & 220.7 \\
\hline OS2 & 416.6 & 37.0 & 45.0 & 1.857 & 10.511 & 189.2 \\
\hline $\mathrm{MC}$ & 364.5 & 32.3 & 39.4 & 1.625 & 9.197 & 165.5 \\
\hline PN & 364.5 & 32.3 & 39.4 & 1.625 & 9.197 & 165.5 \\
\hline WT1 & 329.8 & 29.3 & 35.7 & 1.470 & 8.321 & 149.8 \\
\hline WT2 & 138.9 & 12.3 & 15.0 & 0.619 & 3.504 & 63.1 \\
\hline RO & 399.3 & 35.4 & 43.2 & 1.779 & 10.073 & 181.3 \\
\hline GL1 & 781.2 & 69.3 & 84.5 & 3.481 & 19.708 & 354.7 \\
\hline GL2 & 347.2 & 30.8 & 37.5 & 1.547 & 8.759 & 157.7 \\
\hline SU & 277.7 & 24.6 & 30.0 & 1.238 & 7.007 & 126.1 \\
\hline $\mathrm{BO}$ & 277.7 & 24.6 & 30.0 & 1.238 & 7.007 & 126.1 \\
\hline CR & 260.4 & 23.1 & 28.2 & 1.160 & 6.569 & 118.2 \\
\hline PM & 260.4 & 23.1 & 28.2 & 1.160 & 6.569 & 118.2 \\
\hline Average & 318.0 & 28.2 & 34.4 & 1.417 & 8.024 & 144.4 \\
\hline Min & 138.9 & 12.3 & 15.0 & 0.619 & 3.504 & 63.1 \\
\hline Max & 781.2 & 69.3 & 84.5 & 3.481 & 19.708 & 354.7 \\
\hline \multirow[b]{2}{*}{ Allowable value } & $200-300$ & & 53.33 & $1-2$ & $3-10$ & $170-230$ \\
\hline & [24] & & {$[25]$} & {$[28]$} & [18] & {$[18]$} \\
\hline
\end{tabular}


Figure 1 illustrates the results of $\mathrm{C}$ which perceives that the highest radon concentration was found in GL1 (Gauloises (gold) - France) with a value of (781.2 Bq. $\mathrm{m}^{-3}$ ), while the lowest radon concentration was (138.9 Bq. $\mathrm{m}^{-3}$ ) in WT2 (West (fusion black) - Germany) and PS1(P\&S (black) USA), with an average value of (318.0 Bq. $\left.\mathrm{m}^{-3}\right)$, which is higher than the recommended range (200-300 Bq. $\left.\mathrm{m}^{-3}\right)$ [24]. Twelve out of twenty-eight cigarette samples are higher than the allowable value given by ICRP [24].

The dissolved radon concentration of the brands tobacco cigarette samples varies between $12.3 \times 10^{3}$ Bq. $\mathrm{m}^{-3}$ to $69.3 \times 10^{3}$ Bq. $\mathrm{m}^{-3} \mathrm{with}$ an average value of $28.2 \times 10^{3} \mathrm{~Bq} \cdot \mathrm{m}^{-3}$.

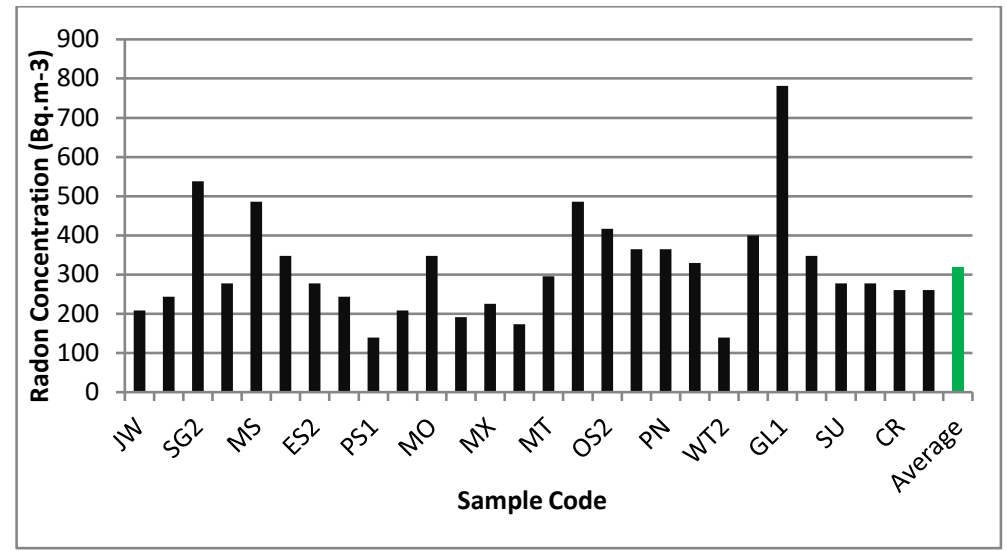

Fig. 1: Radon Gas Concentration in Different Brand Tobacco Samples.

The highest value of PAEC was equal to $(84.5 \mathrm{mWL})$, while its lowest value was equal to (15.0mWL) with an average value (34.4 $\mathrm{mWL}$ ). In all 28 different tobacco cigarettes investigated samples, the results of PAEC were lower than (53.33 mWL) the recommended value reported by the [25] except GL1 and SG2 with values of 84.5 and $58.2 \mathrm{mWL}$, respectively.

The values of EP were ranged from the highest value (3.481 WLM y $\left.{ }^{-1}\right)$ to the lowest value $\left(0.619 \mathrm{WLM}^{-1}\right)$, with a mean value of $(1.416$ WLM. $\left.{ }^{-1}\right)$. All results of EP in the study brand tobacco were lower than the recommended range (1-2 WLM.y $\left.{ }^{-1}\right)$ (NCRP, 1989) except SG2 (2.398 WLM. $\left.{ }^{-1}\right)$, MS and OS1 (2.166 WLM. W $^{-1}$ ) and GL1 with value (3.481 WLM. $\left.{ }^{-1}\right)$.

The annual effective dose (AED) received by the residents ranged from $\left(3.504 \mathrm{mSv}^{-1} \mathrm{y}^{-1}\right)$ to $\left(19.708 \mathrm{mSv} \cdot \mathrm{y}^{-1}\right)$ with a mean value of $(8.024$ $\left.\mathrm{mSv} \cdot \mathrm{y}^{-1}\right)$. AED in all measured tobacco samples were lower than the recommended range (3-10 mSv. $\left.\mathrm{y}^{-1}\right)$ (ICRP, 1993) except SG2 (13.577 $\left.\mathrm{mSv} . \mathrm{y}^{-1}\right), \mathrm{MS}$ and OS1 (12.263 mSv. $\left.\mathrm{y}^{-1}\right)$ and GL1 with value $\left(19.708 \mathrm{mSv} \cdot \mathrm{y}^{-1}\right)$. The results are shown in Figure 2.

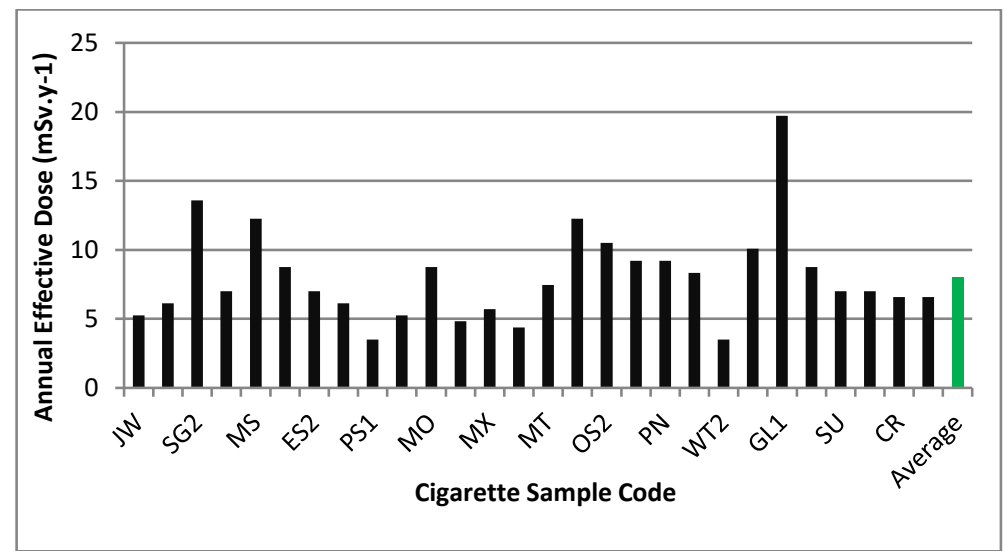

Fig. 2: The Annual Effective Dose (AED) in Different Brand Tobacco Samples.

As well radon concentrations are positively correlated with CPPP as shown in Figure 3.

Lastly, we can say that most of the obtained results presented in this study are comparable with the results given in previous studies made on some tobacco samples used in the Iraqi market [26], [27].

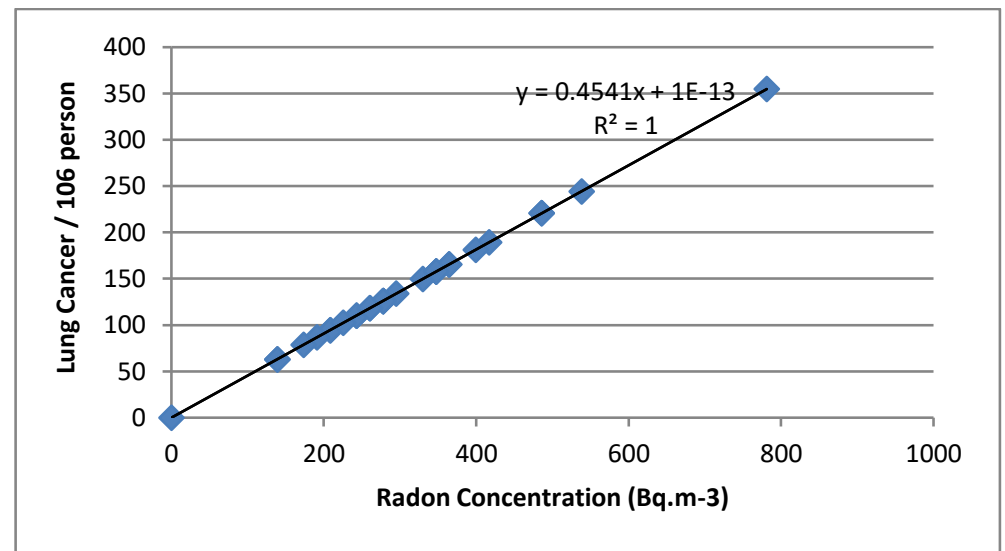

Fig. 3: Positive Correlation between CPPP and Radon Concentration for Tobacco Samples. 


\subsection{Hookah flavor samples}

The measured values of $\mathrm{C}, \mathrm{C}_{\mathrm{Rn}}, \mathrm{PAEC}, \mathrm{EP}, \mathrm{AED}$ and $\mathrm{CPPP}$ in the investigated tobacco cigarette samples are given in Table 4.

Table 4 Radon gas concentration in the various brand hookah samples $\left(\mathrm{C}_{\mathrm{Rn}}\right)$, potential alpha energy concentration (PAEC), exposure to radon progeny (EP), annual effective dose (AED), and lung cancer cases per year per million person (CP PP).

\begin{tabular}{|c|c|c|c|c|c|c|}
\hline Code & $\mathrm{C}$ Bq. $\mathrm{m}^{-3}$ & CRn Bq.m ${ }^{-3}$ & PAEC (mWL) & EP (WLM.y-1) & AED (mSv. $\left.\mathrm{y}^{-} 1\right)$ & $\mathrm{CPPP} \times 10^{-6}$ \\
\hline$\overline{\mathrm{MZ1}}$ & 512.1 & 45.4 & 55.4 & 2.282 & 12.919 & 232.6 \\
\hline MZ2 & 460.0 & 40.8 & 49.7 & 2.050 & 11.606 & 208.9 \\
\hline MZ3 & 451.3 & 40.0 & 48.8 & 2.011 & 11.387 & 205.0 \\
\hline FR & 442.7 & 39.3 & 47.9 & 1.973 & 11.168 & 201.0 \\
\hline $\mathrm{AD}$ & 512.1 & 45.4 & 55.4 & 2.282 & 12.920 & 232.6 \\
\hline FM & 598.9 & 53.1 & 64.7 & 2.669 & 15.109 & 272.0 \\
\hline AM & 416.6 & 37.0 & 45.0 & 1.857 & 10.511 & 189.2 \\
\hline $\mathrm{ZC}$ & 633.6 & 56.2 & 68.5 & 2.824 & 15.985 & 287.7 \\
\hline $\mathrm{RZ}$ & 546.8 & 48.5 & 59.1 & 2.437 & 13.796 & 248.3 \\
\hline DJ & 520.8 & 46.2 & 56.3 & 2.321 & 13.139 & 236.5 \\
\hline Average & 509.5 & 45.2 & 55.1 & 2.271 & 12.854 & 231.4 \\
\hline Min & 416.6 & 37.0 & 45.0 & 1.857 & 10.511 & 189.2 \\
\hline Max & 633.6 & 56.2 & 68.5 & 2.824 & 15.985 & 287.7 \\
\hline
\end{tabular}

The results reveal that the highest radon concentration was found in ZC (Zain, Castro - France) with a value of $\left(633.6\right.$ Bq. $\left.\mathrm{m}^{-3}\right)$, while the lowest radon concentration was (416.6 Bq. $\mathrm{m}^{-3}$ ) in AM (Al Amasi - Germany), with an average value of (509.5 Bq. ${ }^{-3}$ ), which is higher than the recommended range (200-300 Bq. $\left.\mathrm{m}^{-3}\right)$ [24]. The obtained results are shown in Figure 4.

The values of $\mathrm{C}_{\mathrm{Rn}}$ of the tobacco hookah samples were ranged between $\left(37.0 \times 10^{3)} \mathrm{Bq} \cdot \mathrm{m}^{-3}\right.$ to $\left(56.2 \times 10^{3}\right)$ Bq. $\mathrm{m}^{-3}$ with a mean value of $\left(45.2 \times 10^{3}\right)$ Bq. $\mathrm{m}^{-3}$.

PAEC values were ranged from the highest value $(68.5 \mathrm{mWL})$ to the lowest value of equal to $(45.0 \mathrm{mWL})$ with an average value (55.1 $\mathrm{mWL}$ ). The results of (PAEC) for 6 hookah samples (MZ1, AD, FM, ZC, RZ and DJ) are higher than the (53.33 mWL) the recommended value given by the [25], while the results of the other 4 hookah samples (MZ2, MZ3, FR and AM) show lower values than the recommended value.

The average value of EP was (2.271 WLM.y $\left.{ }^{-1}\right)$ where the greatest EP value was equal to (2.824 WLM.y ${ }^{-1}$ ), while the lowest value of EP was equal to $\left(1.857 \mathrm{WLM}_{\mathrm{y}}{ }^{-1}\right)$. All EP values of the study hookah flavor samples were higher than the range $\left(1-2 \mathrm{WLM}^{-1}\right)$ recommended by NCRP [28] except for AM and FR which show lower values than the recommended range.

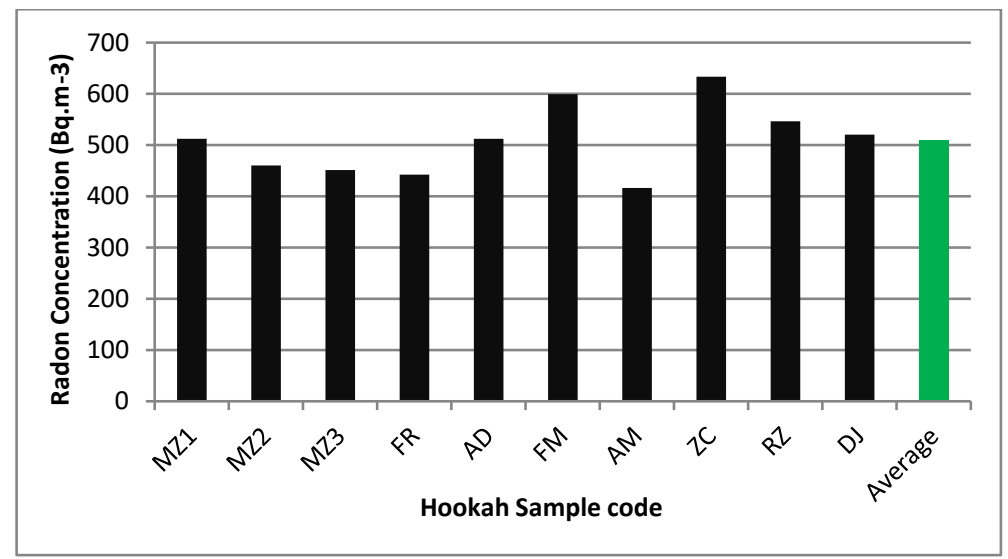

Fig. 4: Radon Gas Concentration in Study Brand of Hookah Flavor Samples.

The annual effective dose (AED) received by the residents varies from $\left(10.511 \mathrm{mSv} \cdot \mathrm{y}^{-1}\right)$ to $\left(15.985 \mathrm{mSv} \cdot \mathrm{y}^{-1}\right)$ with an average value of $\left(12.854 \mathrm{mSv} \cdot \mathrm{y}^{-1}\right)$. AED in all measured hookah flavor samples are higher than the recommended range (3-10 mSv. $\left.\mathrm{y}^{-1}\right)$ [18]. The results of AED are shown in Figure 5.

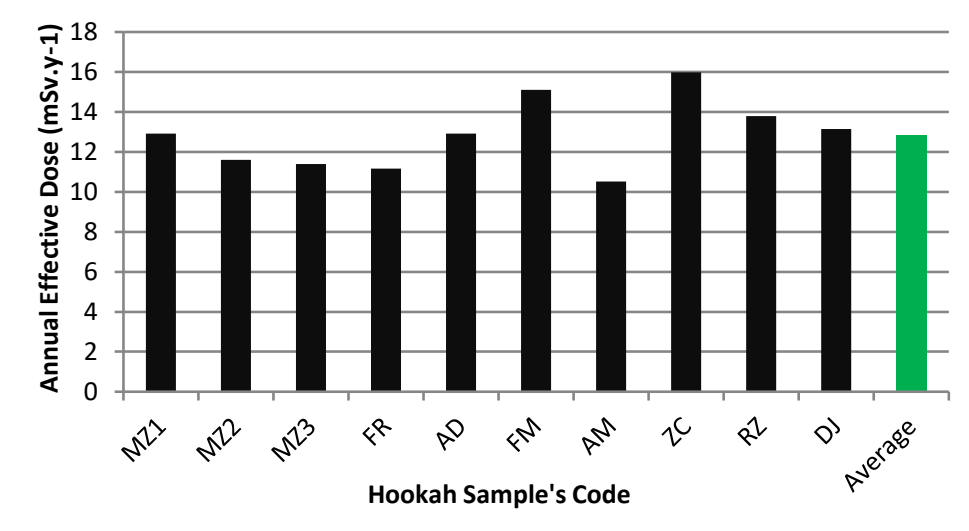

Fig. 5: The Annual Effective Dose (AED) in Study Brand of Hookah Flavor Samples. 
Figure 6 illustrates the positive correlation between the radon concentrations and CPPP for hookah samples. The present obtained results are higher than the results reported in the previous studies made on some hookah flavor samples used in the Iraqi market [29].

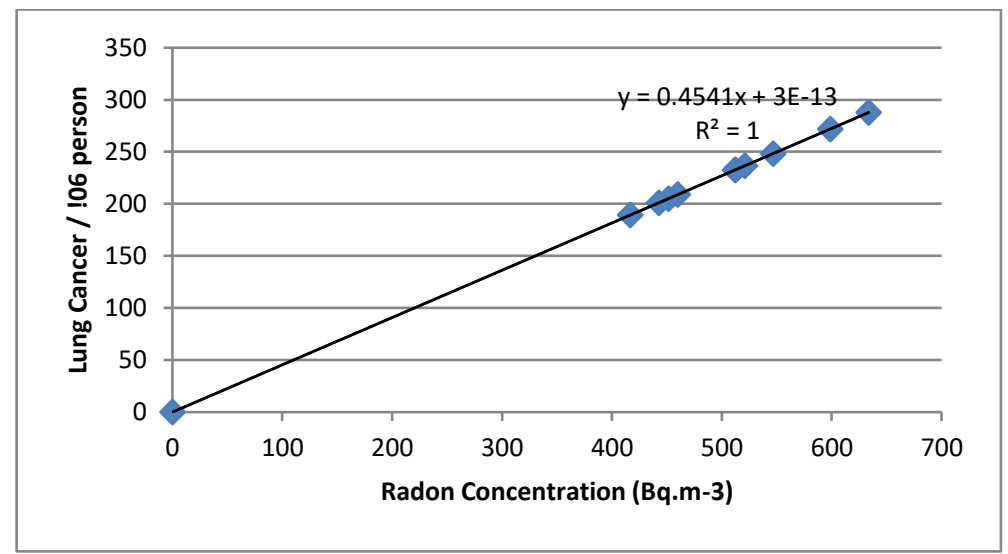

Fig. 6: Positive Correlation between CPPP and Radon Concentration for Hookah Flavor Samples.

\section{Conclusions}

Tobacco smoking is lethal from numerous points of view and it has genuine wellbeing, financial, and social outcomes. Despite the fact that the common radioactive materials in tobacco and hookah can be considered as one of the fundamental purposes behind the health effects of smoking cigarettes or hookah, there are very restricted published researches on the concentration of natural radioisotopes in tobacco. Moreover, the concentration of radioactive isotopes content in tobacco differs within the same brands of cigarette as well as same brands of hookah. Furthermore, the measured radon concentrations in both tobaccos of cigarettes or hookah samples are found greater than the recommended range given by ICRP.

The estimated radiological impacts indices calculated in this work such as PAEC, EP and AED in most tobacco cigarette samples were found to be lower than the recommended value. While only 6 samples of hookah tobacco were found to be lower than the recommended value.

The excess lifetime cancer risks values estimated were also lower than the recommended limits given by ICRP except GL1 and SG2 cigarette samples and FM, ZC, RZ and DJ hookah samples. This represents a genuine malignant growth hazard and some other radiation wounds to the smokers and passive smokers in the environment. So, It can then be deduced that various factors, for example, the planting area where the tobacco plant is grown, the cultivation of the tobacco, the size and composition of the filter, manufacturing procedures, age of the products and smoking habits govern the degree of exposure via the path way of tobacco.

From the present work we found that according to the International Commission of Radiological Protection, the results reveal that 16 of cigarette tobacco samples are within the allowable limits, while all the hookah tobacco samples are higher than the allowable limits. Hence, we can conclude that the radioactivity content in hookah products was higher than that of the cigarette products, so, hookah flavor may add risk of lung malignancy to that due to tobacco for smokers.

\section{Acknowledgments}

I would like to express my special thanks to Environmental Research Center- University of Technology for providing me with all facilities that were required in completing this project. As well as, I would like to thank all my colleagues in the Center for sharing their experience and for their support.

\section{Conflict of interest}

The author has no conflicts of interest to disclose.

\section{References}

[1] O. Naomi, M. C. Erik, Merchants of Doubts: How a handful of scientists obscured the truth on issues from tobacco smoke to global warming, Bloombury Press, London, (2010) 34-41.

[2] J. Winickoff, E. Muggli, J. Harrison, J. Friebely, S. Tanski, C. Sherrod, G. Matt, M. Hovell, R. McMillen, Beliefs about the Health Effects of Third hand Smoke and Home Smoking Bans, Pediatrics 13(1) (2009) 74-79 https://doi.org/10.1542/peds.2008-2184.

[3] Kh. H. Abass, M. S. Karim, Determination of alpha particles concentration in Clay Bricks Samples by CR-39 Detector, Journal of Babylon University: Pure and Applied Sciences 22(6) (2014) 1816-1819.

[4] P. Thangaraju, G. Barkavi, T. Karthikeyan, Mining lung cancer data for smokers and non-smokers by using data mining techniques, International Journal of Advanced Research in Computer and Communication Engineering 3(7) (2014) 7622-7626.

[5] World Health Organization (WHO) Information sheet, Radon and Health (2002) http://www.who.int/ionizing_radiation/env/Radon_Info_sheet.pdf

[6] Y.W. Yi, Experimental determination of parameters of tracks on solid statenuclear track detectors from alpha particles with different incident energies and angles. M.Sc. Thesis, City University of Hong Kong (2004).

[7] L. Ponte, Radioactivity: The New-Found Danger in Cigarettes, Reader's Digest, Chappaqua, New York (1986) 123-127.

[8] H. A. A. Ghany, The association between indoor radon and tobacco smoke, Indoor Built Environ 15 (2006) 289-293. https://doi.org/10.1177/1420326X06066335.

[9] H. A. A. Ghany (2007) Enhancement of radon exposure in smoking area, Environmental Geochemistry and Health 29 (2007) $249-255$. https://doi.org/10.1007/s10653-007-9082-4. 
[10] A. F. Hafez, A. S. Hussein, Radon activity concentrations and effective dose in ancient Egyptian tombs of the Valley of the Kings, Applied Radiation and Isotopes 55 (2001) 355-362. https://doi.org/10.1016/S0969-8043(01)00065-3.

[11] V. Z. Hamza, M. N. Mohankumar, Cytogenetic damage in human blood lymphocytes exposed in vitro to radon, Mutation Research 661 (2009) 1-9. https://doi.org/10.1016/j.mrfmmm.2008.10.010.

[12] A. K. Hashim, L. A. Najam, Radium and uranium concentrations measurements in vegetables samples of Iraq, Detection 3 (2015) 21-28. https://doi.org/10.4236/detection.2015.34004.

[13] G. Somogi, A. Hafez, I. Hunyadi, M. Toth- Szilagyi, Measurement of exhalation and diffusion parameters of radon in solids by plastic track detectors, Nuclear Tracks and Radiation Measurements 12(1-6) (1986) 701-704. https://doi.org/10.1016/1359-0189(86)90683-7.

[14] B. Al-Bataina, A. Ismail, M. Kullab, K. Abumurad, H. Mustafa, Radon measurements in different types of natural waters in Jordan, Radiation Measurement 28(1) (1997) 591-594. https://doi.org/10.1016/S1350-4487(97)00146-7.

[15] A. H. Ismail, Z. A. Hussyin, Study of seasonal variations of radon levels and its risks inside different schools in Iraqi Kurdistan region for the first time, Proceeding of the 10th International Conference on Environmental Science and Technology KOS island, Greece, 5-7 September, (2007) B$305-\mathrm{B} 317$.

[16] A. H. Ismail, M. S. Jaafar, Indoor radon concentration and its health risks in selected locations in Iraqi Kurdistan using CR-39 NTDs, Bioinformatics and Biomedical Engineering (ICBBE), 4th international Conference in Cheng du ,18-20 June (2010). https://doi.org/10.1109/ICBBE.2010.5514794.

[17] S. Kansal, R. Mehra, N. P. Singh, (2012) Life time fatality risk assessment due to variation of indoor radon concentration in dwellings in western Haryana, India, Applied Radiation and Isotopes 70 (2012) 1110-1112. https://doi.org/10.1016/j.apradiso.2011.11.057.

[18] International Commission on Radiological Protection Publication (ICRP) Protection against Radon-222 at home and at work. Annals of ICRP: Oxford: Pergamon press (1994) 1-45.

[19] A. M. Mowlavi, M. R. Fornasier, A. Binesh, M. de Denaro, Indoor radon measurement and effective dose assessment of 150 apartments in Mashhad, Iran. Environmental Monitoring Assessment 184 (2012) 1085-1088. https://doi.org/10.1007/s10661-011-2022-x.

[20] United Nations Scientific Committee (UNSCEAR), The Effects of Atomic Radiation: Sources and Effects of Ionizing Radiation, United Nations, New York (2000).

[21] K. M. Abumurad, R. A. Al-Omari, Indoor radon levels in Irbid and health risks from internal doses. Radiation Measurements 43 (2008) S389-S391. https://doi.org/10.1016/j.radmeas.2008.03.051.

[22] H. H. Mansour, Measurement of indoor radon level in Arbil capital by using solid state nuclear track detectors, Radiation measurement 40 (2005) 544-547. https://doi.org/10.1016/j.radmeas.2005.06.033.

[23] A. A. Abdullah, Internal and external radiation exposure evaluation amongst selected workers and locations in Iraq. Ph.D. Thesis. University Sains Malaysia, Malaysia (2013).

[24] International Commission on Radiological Protection Publication (ICRP), Statement on Radon, Ref. 00/902/09 (2009).

[25] United Nations Scientific Committee (UNSCEAR), Sources and effects of ionizing radiation. United Nations Publication E $94.1 X$; 2 (1993) 33-89.

[26] A. K. Hashim, L. A. Najam, L. Tettey-Larbi, A study of radon concentration in different brands tobacco cigarette in Iraqi market, influencing factors and lung cancer risk, International Journal of Science and Technology 5(10) (2015).

[27] A. K. Hashim, L. A. Najam, A. F. Hadi, Kh. F. Fuliful, Lung cancer risk due to radon in different brand cigarette tobacco in Iraqi market, World Scientific News (WSN) 77(2) (2017) 163-176.

[28] National Council on Radiation Protection and Measurements (NCRP), Control of radon in houses, Report No. 103 (1989).

[29] A. N. Sabbar, H. S. Naeem, Measurement of radon concentration in hookah flavor, International Journal of Scientific Engineering and Technology 5(5) (2016) 272-274. doi : 10.17950/ijset/v5s5/512. 